\title{
IMPROVING THE STUDENTS' LISTENING COMPREHENSION THROUGH AURAL-ORAL LANGUAGE APPROACH
}

\author{
Sujariati \\ Universitas Muhammadiyah Makassar \\ yatisujar@gmail.com
}

Submit, 16-05-2020 Accepted, 30-06-2020 Publish, 30-06-2020

\begin{abstract}
This research aimed to know the effectiveness of using Aural-oral approach to improve the students' listening comprehension, and to know the students' activeness toward teaching learning process through Aural-oral approach at the eleventh grade students of SMAN 1 Makassar. Two cycles had been conducted, where each cycle consisted of four meetings. It implemented Aural-oral approach as an approach to improve the students' listening comprehension and employed listening test as instrument. A number of subjects of the research were 16 students. It is consist of 9 women and 7 men. The researcher took real data from the school to know the students' listening comprehension. The students' mean score of listening achievement at D-Test was 50.69, at the cycle I was 65.28 and at the cycle II was 75.93. The result of the student's listening test in cycle II had improved in significant score, where the means score of students in distinguish phonemes was 87.5, in understanding Statement was 50, and in understanding dialogue was 90.28. It means that the students' mean score at the cycle II was 75.93 reached the target score 75 and the students' activeness toward teaching learning process by using Aural-oral approach was improved. It can be seen from the observation result of the students' activeness in the classroom from the first meeting at the first cycle until at the last meeting in cycle II always grow up. It could be stated that the research was successful.
\end{abstract}

Keyword: Listening Comprehension, Aural-oral Approach, Student' Listening, Student's Activeness

\section{INTRODUCTION}

Listening is one of English skill and English study that is quite difficult for students at senior high school. The lack of interest and motivation of the students is one of the problem in studying it. It may be caused by the methods and techniques that are not suitable with the students' need or the students' interest. Of course it can be the serious problems for the students. As the result, they are not enthusiastic in learning English and it can influence their achievement such as in listening comprehension. The skills in listening comprehension also should be separated in 
testing or teaching in order to reach the good achievement in listening comprehension.

Based on the information from an English teacher of SMAN 1 Makassar through observation to the teaching learning process in the classroom, especially at the eleventh grade, the students' achievement in Listening comprehension is low. As a value observation in the classroom the students' score is about 5 , in the last semester the students score between $50-65$ while the KKM is 70 . This score is as a category poor. It is because the students seldom practice listening in teaching-learning process but they tend to focus on writing and grammar. Therefore, I want to overcome this problem until the students get a good achievement by using an approach that related to the student's problem has been talked.

As long some approaches had been applied to improve the students' listening comprehension at the school, but those approaches still weak, in the other words those approaches are not significant to improve the students' achievement in listening comprehension. In this case the I would like to introduce an approach that is assumed to be success to improve the students' listening comprehension. It is called AuralOral Language Approach.

According to Buck, (2001) in Aural-Oral Language Approach is a method to the teaching language that emphazise on mechanical drills and repetition. It focuses on mechanical repetition through the use of oral drills lead also to complete neglience of creative use of language and cognition.

Buck (2001) states during World War II the American military need a quick and effective way to teach foreign language skills in order to understand the oral communication of the enemy. Then they arrange the programs of second language teaching field back to focusing on teaching listening and speaking skills. The programs developed by the American structural linguistics of the 1940's then relied heavily on oral drills and substitution practice in order to form these speaking habits among language students. The result was aural-oral approach that became known as the Audio-Lingual Method (Buck, 2001).

Drilling is a key feature of Audio-Lingual Method as the result of Aural-Oral language approach to language teaching which placed emphasis on repeating structural patterns through oral practice. There are some good points that teachers may find when they use Aural-Oral Method in their teaching, namely: (1) the classroom activity, which is the teacher's centered so that it makes the teacher easier to manage the students (2) the usage of the target language in the classroom, which is meant to make the students have the same abilities that the native speakers have (3) the classroom activity, which focuses on pattern drills so that the teacher only gives brief explanation, and focus on oral skills leading to good pronunciation and speech (Larsen et al., 2018).

Refers to several years ago, some studies by some researchers had done research dealt with Listening skill through Aural-Oral approach. Absolutely, there were some differences with that such as the research design, sample, and methodology, then the findings. Some researches namely, Kayalar, (2017) with focused 
on investigating the effect of auditory learning listening. Which had found that using Aural oral intensively could help the students to increase the students memory. Then Gilakjani \& Ahmadi, (2011) findings based on the review of the literature along with analysis of the data are of great significance and can be advantageous to improve EFL learners' English listening comprehension skill.

Agulló \& Bueno-Alastuey (2017) with their study examines oral/aural competence in the most commonly used course books for writing and listening in the second year of Baccalaureate in Spain. Then the result findings showed that the proportion of tasks 1 and task 2 devoted to oral/aural and written skills was similar. Other research dealt with the application of Aural-Oral approach come from Gilakjani \& Sabouri, (2016) which focused on "Spoken English" courses was higher in the case of the experiment group in which the computer was used as an aided tool for teaching.

Moreover, for international school, the method was implemented by one researcher (Itticharoenporn, n.d. 2014) the study investigated teachers, parents, and students perceive informal speaking and listening in situations such as pair work, small group discussion, out-of-class study groups to communicate with teachers. Then Namaziandost \& Nasri, (2018), explored the impacts of audio-visual aids among Iranian pre-intermediate EFL learners on teaching listening. The study indicate that using audio-visual aids can help EFL students grow their understanding of. The other research from Huang, (2019) also have investigated the progressing of students listening by doing a research which focus on how to teach aural english more effectively where the findings of the research there was significant improvement of listening achievement by using aural english teaching that involves the teaching patterns, teachers' and students' roles in class and the correlation between exams and development of abilities.

Other research also from Ahmadi \& Seyedeh, (2016) with the same skill of listening and only focuses on the importance of listening comprehension in language learning through effective aural-oral-audio. Then Finally, research from Abduh, (2016) also did research used aural-oral method in listening skill in different design. The research was to help the teachers in teaching listening to students, teachers may use an interesting teaching method to present their teaching materials that also help them in creating a fun class. After conducting the research, the students' means score showed the improvement in cycle 2. It is concluded that using audio-lingual could help to improve students' listening comprehension. It means that, Aural-Oral approach had improved the students listening comprehension effectively.

The use of Aural-Oral approach is very interesting, so not only two or three expert's interested in but also other people like teacher, lecturer, and students. Furthermore, the method had been applied not only for national school but also international school. Based on the previous findings above, participated Aural-Oral method is a good way of recent concerns in teaching and learning foreign language education that has generated a stronger focus on listening in the classroom. The method is one of the necessities of teachers to teach through aural English more 
effectively so as to improve students' aural ability. All the findings above showed that the method was effective and produced many advantages for teaching and learning English in the classroom.

However, all the previous studies only focused on listening skill and achieved the data through descriptive qualitative and experimental design. While in this research, it focused on statement dialogue of listening achievement and the effectiveness the students in learning Listening by using the method. Besides, the implementation of the aural-oral approach is by action research which involved an activities in the process. Essentially, this research is very effective than other research because I applied aural-oral approach by integrating listening with teaching activities so the activities in aural-oral approach in this research is make different and more valuable than the other research. Through the activities, Students mix up with accurate aural perception can often reproduce sounds they hear without having the slightest idea of what the words mean. The action research applied with repetition to make sure the maximal act to be perfect outcome. However, student face more complex the material is reproduced, the more difficult it is to repeat it accurately without understanding but it does not mean that the students could not do it. Besides, the students is very enthusiastic and enjoyable.

Furthermore, the most important thing with this research is some useful practices had obtained by the use of pair-work or group-work (students take turns to repeat it). All the activities through Aural-Oral diversify the patterns of class and improve students' aural abilities. Finally, this research is valuable and very useful for students, teachers, and readers. This research gives greater and more contribution to Teaching English as Foreign Language (TEFL). Therefore, this research need to do to cover the lack of the previous research.

\section{LITERATURE REVIEW}

\section{The Concepts of Aural-Oral Language Approach}

Aural-Oral Language Approach is an approach to the teaching language that emphazise on mechanical drills and repetition. It focus on mechanical repetition trough the use of orall drills lead also to complete neglience of creative use of language and cognition. (Butler, 2017) says that in the United States, the oral/aural approach is historically the oldest. Oral is approach of deaf education have believed that deaf children are best served by instruction in lip-reading, in maximum use of residual hearing (through amplification and auditory training), and in articulation to improve speech.

Aural-Oral Communication places the emphasis on the use of speech, residual hearing and in some cases, speech reading (lip-reading.) Early identification of hearing loss, consistent use of optimal amplification during all waking hours, assistive listening devices or use of cochlear implants is critical to following this philosophy since the child needs to understand the spoken word. The student, for its 
part continually attempts to mimic what the teacher said. Each day, as the young child matures, it makes rapid progress in comprehending what the mother says, and it reproducing what it hears. First one and two word utterances and then progressing on to phrases of several words and finally complete sentences.

Zulfiqar, (2015) notes in language classes at these centers the native speaker instructors would say a word, phrase, or sentence and then have the students in the class say the same word, phrase, or sentence aloud, both individually and as a group. Then the native speaker instructor will say the same word, phrase, or sentence again, and have the students say it again aloud. This process is repeated until all of the students in the class can say a given word, phrase, or sentence with more or less the same pronunciation and speed as the native speaker instructor. Then the teacher will go on to the next word, phrase, or sentence in a lesson and repeat the whole process again.

In the highly intensive programs (usually at least five hours a day of classroom teaching and in classes with a small number of students and under the quite regimented condition in the military language schools, this method works quite well, and thousands of military personnel are trained to speak a second language in fairly short period (Zulfiqar A. Bin Tahir, 2015).

\section{Kinds of Aural-Oral Language Approach}

There are three kinds of this approaches are as follows Butler (2001).

\section{Auditory-Oral Approach}

a. This approach combines speech, use of residual hearing and speech reading.

b. This approach is more traditional of the auditory verbal/oral approaches.

c. The student will be trained to use his or her hearing and develop expressive speech.

d. Pure oral strongly emphasizes no signing and speech is the only acceptable means response.

e. The goal of this approach is to have the student mainstream into the students' regular school after having completed an oral deaf or hard of hearing special education program.

\section{Auditory-Verbal Approach}

a. Although the auditory-oral emphasize speech-reading, this method does not.

b. The student is taught to listen first and is not required to look at the speaker's mouth for information.

c. Often, the student is mainstream from the start in a typical preschool rather than a special self-contained oral program. 
d. This method emphasize the increase like hood that student, hard of hearing, can be educated to use even minimal amounts of residual hearing permits these students to learn to listen, process verbal language, and to speak.

e. With this method, disadvantages that are connected with dependence on speech-reading are eliminated.

\section{Auditory training}

a. Auditory training is teaching person with a hearing impairment how to use the residual or remaining hearing that is available to them with the goal of maximizing use of speech and non-speech cues. In developing an approach to auditory training, it is important that the clinician consider the amount of hearing that the client has.

b. Clients with aided hearing levels in the mild to moderately severe hearing range will work on sound discrimination skills.

c. Clients with aided hearing levels within the severe to profound hearing loss range will improve the detection of sounds, particularly environment sounds. Therefore, the person may develop at least a functional use of hearing.

d. The emphasized is on the auditory skills that may be delayed or missing altogether.

\section{The Strategies of Using Aural-Oral Approach in the Classroom}

These are some strategies that can be used in teaching language based on listening comprehension through Aural- Oral Language Approaches:

1. Attend out-of-class events or being an overly active listener

2. Listening for key words that carry the bulk of the meaning

3. Consciously attending activities and imitating is especially great to listening abilities, where being exposed and forced to listen to talk are most effective.

4. Imitate the way native speakers or the teacher talks. By paying particularly close attention to things like emphasis, stressed-syllables, pauses, gestures, and articulations, one can develop a more naturalistic stream of speech. Through understanding the flow of the language, one is able to move away from simply the textbook approach.

5. Ask the teacher about unfamiliar sounds that the students hear, especially during a conversation, can help them form a deep impression of the specific words. It is also a nice way to get clarification right away.

6. Look for associations between the sound of a word or phrase and practice sounds in the target language. Because there are some particular different pronunciations. 
7. Placing the students in settings where they can effectively work on the language skills and in situations where they can increase them selves to exposure of the language.

8. Develop bonds with peers and native speakers or teacher. This is very important because if one is able to make strong connections with native speakers or teacher is to have many conversations with them, it is easy to enhance language skills of the students if they are in a more comfortable setting. They will enjoy asking or clarifying questions.

In language classes at these centers the teacher will say a word, phrase, or sentence and ask the students in the class to say the same word, phrase, or sentence aloud, both individually and as a group. This process is repeated until all of the students in the class can say a given word, phrase, or sentence with more or less the same pronunciation and speed as the native speaker instructor. Then the teacher will go on to the next word, phrase, or sentence in a lesson and repeat the whole process again. ( Ahmadi Seyyedeh M 2016).

\section{The Concepts of Listening}

Listening means to pay attention to somebody/something that you can hear. Based on this definition, it can be concluded that listening is process to attend and interpret spoken language or a process of transferring information from an oral/spoken language. Bowen in his book "Tessol Techniques and Procedures" explains that, 'Listening is occasionally referred to as a passive skill. This interpretation oversimplifies the definition of listening; a listener is far from passive as he receives, analyze, and interpret the oral signal that come his way, recreating the massage of the speaker. More carefully specified, listening is attending to and interpreting oral language interpreting oral language. The students should be able to hear oral speech in English, segment the stream of sounds, group them into lexical and syntactic unit (word, phrase, and sentence) and understand the massage they convey' (Sharp et all, 2010). Ivone \& Renandya, (2019) stated that definition of listening includes active listening which goes beyond comprehending. Such as understanding the messages content to comprehend an act of emphatic understanding of the speaker. Buck (2001) argues that empathy is the essential to listening and contends that is more than polite attempt to identify a speaker's perfectives. 


\section{RESEARCH METHOD}

This research used classroom action research (CAR) that consisted of planning, action, observation and reflecting. It had been conducted in two cycles each cycle comprises four meetings. After finding the result of cycle one, the researcher continued to the second cycle to improve the prior cycle. In the two cycle were each cycle was the series of activity which has close relation. Where, the realization of the second cycle was continuing and repairing from the first cycle. In this section, the researcher used two instruments for collecting data:

1. Test. The test was used to get the students' listening achievement trough AuralOral approach. The test had been given before action of cycle one started. It was considered as the diagnostic test. At the end of each cycle a test had been given to measure the students' improvement.

2. Observation. It aimed at finding out the students' participation or activeness during the teaching and learning process trough Aural-Oral language approach.

The data collected through the listening test had been analysed by using the following formula:

1. Scoring the students' answer by using this formula

$$
\text { Students' Score }=\frac{\text { total Score }}{\text { Maximum Score }} \times 100
$$

2. Classifying the score of the students listening test from the first and second cycle. Classifying the students' score into seven levels are follows:

\begin{tabular}{cc}
\hline Classification & Score \\
\hline Excellent & $90-100$ \\
\hline Very Good & $80-89$ \\
\hline Good & $70-79$ \\
\hline Fair & $60-69$ \\
\hline Poor & $0-59$ \\
\hline
\end{tabular}

3. Finding out the students' mean score in both first cycle and second cycle by using this formula :

$$
\bar{X}=\frac{\sum X}{N}
$$

Where: $\bar{X}$ : Mean score of the students

$\sum X$ : Total row score

$\mathrm{N}:$ The total respondent 
4. To analyze the percentage technique by using the following formula:

$$
\begin{aligned}
& \quad \mathbf{P}=\frac{F}{N} \boldsymbol{x} \mathbf{1 0 0} \\
& \mathrm{P}=\text { percentage } \\
& \mathrm{F}=\text { Number of correct } \\
& \mathrm{N}=\text { Number of sample }
\end{aligned}
$$

5. To score of the students' active participation find out by using the following formula:

$$
P=F q \frac{X 100}{4 \times N}
$$

$\mathrm{Fq}:$ Frequency

$\mathrm{P}$ : Percentage

$\mathrm{N}$ : Sum of Subject

6. To know the percentage of the students' improvement:

$\mathrm{P}=\frac{x 2-x 1}{x 1} x 100$

Where: $\mathrm{P}=$ Percentage

$\mathrm{X} 1$ = mean score of cycle I

$\mathrm{X} 2=$ mean score of cycle II

\section{FINDINGS}

\section{Distinguish Phonemes}

The Students' Mean Score in Listening Component of Distinguish Phonemes.

Tabel 1 The Improvement of the Students' Listening in Distinguish Phonemes

\begin{tabular}{cccc}
\hline D-test & Cycle & Improvement & Mean score \\
\hline \multirow{2}{*}{66.67} & I & 21.87 & 81.25 \\
\cline { 2 - 4 } & II & 7.69 & 87.5 \\
\hline
\end{tabular}

The data above can also be shown from the graphic below:

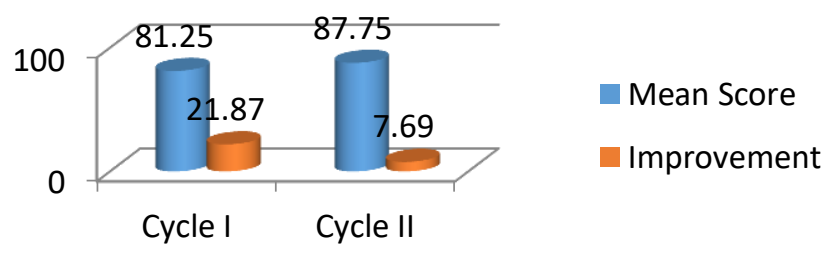

Graphic 1: The Improvement of the Students' Listening in Distinguish Phonemes 
The students' Tabulation of Frequency in Listening Component of Distinguish Phonemes

Based on the data analysis the students' score in distinguish phonemes are got from the result of the test in cycle I and cycle II in the following table and graphic is presented:

Table 2. The Students' Tabulation of Frequency in Distinguish Phonemes

\begin{tabular}{cccccc}
\hline Classification & Score & \multicolumn{2}{c}{ Frequency } & \multicolumn{2}{c}{ Percentage } \\
\cline { 2 - 6 } & & Cycle I & Cycle II & Cycle I & Cycle II \\
\hline Excellent & $\mathbf{9 0 - 1 0 0}$ & $\mathbf{7}$ & $\mathbf{1 0}$ & $\mathbf{4 3 . 7 5}$ & $\mathbf{6 2 . 5}$ \\
\hline Very Good & $\mathbf{8 0 - 8 9}$ & & & & \\
\hline Good & $\mathbf{7 0 - 7 9}$ & & & & \\
\hline Fair & $\mathbf{6 0 - 6 9}$ & $\mathbf{9}$ & $\mathbf{6}$ & $\mathbf{5 6 . 2 5}$ & $\mathbf{3 7 . 5}$ \\
\hline Poor & $\mathbf{0 - 5 9}$ & & & & \\
\hline Total & & $\mathbf{1 6}$ & $\mathbf{1 6}$ & $\mathbf{1 0 0}$ & $\mathbf{1 0 0}$ \\
\hline
\end{tabular}

The data above can also be shown in the graphic below:

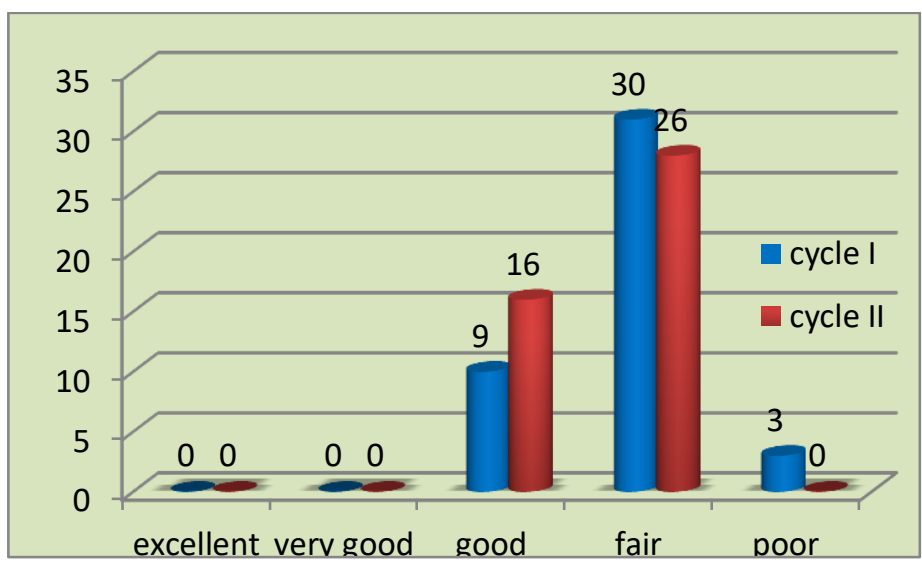

Graphic 2: The Students' Tabulation of Frequency in Distinguish phonemes

Based on the table 2 and the graphic 2 above show that in cycle I there are 7 students (43.75) get excellent and there are 9 students $(56.25 \%)$ get fair. While in cycle II there is no student get poor, there are 10 students $(62.5 \%)$ get excellent and 6 students $(37.5 \%)$ get fair. 
Understanding Statements.

The students' Mean score in listening component of understanding statements.

Table 3. The Students' Mean Score in Understanding Statements.

\begin{tabular}{cccc}
\hline D-test & Cycle & Improvement & Mean score \\
\hline \multirow{2}{*}{45.83} & I & 4.54 & 47.91 \\
\cline { 2 - 4 } & II & 4.36 & 50 \\
\hline
\end{tabular}

The data above can also be shown in the graphic below:

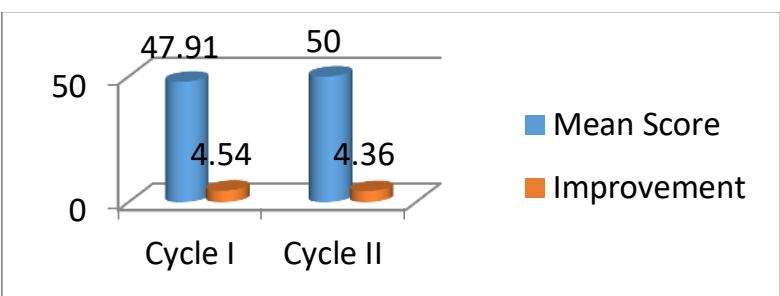

Graphic 3: The Improvement of the Students' Understanding statements.

\section{The Students' Tabulation of Frequency in Understanding Statements}

Based on the data analysis the students' score in understanding statements are got from the result of the test in cycle I and cycle II in the following table and graphic is presented:

Table 4. The Students' Tabulation of Frequency in Understanding statements

\begin{tabular}{cccccc}
\hline Classification & Score & \multicolumn{2}{c}{ Frequency } & \multicolumn{2}{c}{ Percentage } \\
\cline { 2 - 6 } & & Cycle I & Cycle II & Cycle I & Cycle II \\
\hline Excellent & $\mathbf{9 0 - 1 0 0}$ & & & & \\
\hline Very Good & $\mathbf{8 0 - 8 9}$ & & & & \\
\hline Good & $\mathbf{7 0 - 7 9}$ & & & 37.5 & 43.75 \\
\hline Fair & $\mathbf{6 0 - 6 9}$ & $\mathbf{6}$ & $\mathbf{7}$ & $\mathbf{6 2 . 5}$ & $\mathbf{5 6 . 2 5}$ \\
\hline Poor & $\mathbf{0 - 5 9}$ & $\mathbf{1 0}$ & $\mathbf{9}$ & $\mathbf{1 0 0}$ & $\mathbf{1 0 0}$ \\
\hline Total & & $\mathbf{1 6}$ & $\mathbf{1 6}$ & & \\
\hline
\end{tabular}


The data above can also be shown in the graphic below:

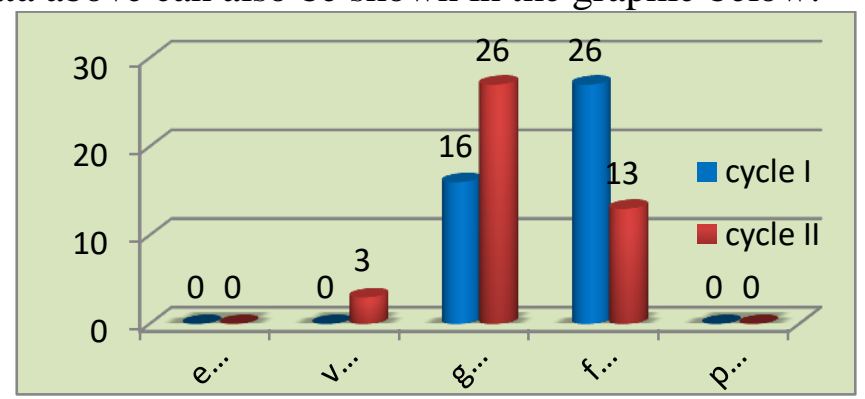

Graphic 4: The Students' Tabulation of Frequency in Understanding Statements

\section{Understanding Dialogue.}

The Students' Mean Score in Listening Component of Understanding Dialogue.

Table 5. The students' mean score in Understanding Dialogue.

\begin{tabular}{cccc}
\hline D-test & Cycle & Improvement & Mean score \\
\hline \multirow{2}{*}{39.58} & & & \\
\cline { 2 - 4 } & I & 68.44 & 66.67 \\
\hline
\end{tabular}

The data above can also be shown from the graphic below:

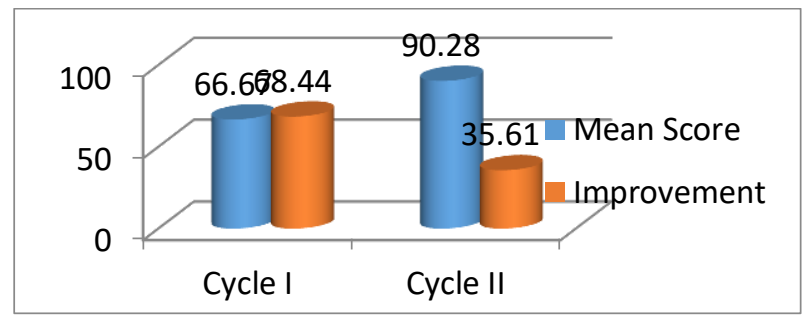

Graphic 5: The Improvement of the Students' Listening in understanding dialogue

The students' Tabulation of Frequency in Listening Component of understanding dialogue

Based on the data analysis the students' score in understanding dialogue are got from the result of the test in cycle I and cycle II in the following table and graphic is presented: 
Table 6. The Students' Tabulation of Frequency in Understanding Dialogue

\begin{tabular}{cccccc}
\hline Classification & Score & \multicolumn{2}{c}{ Frequency } & \multicolumn{2}{c}{ Percentage } \\
\cline { 2 - 6 } & & Cycle I & Cycle II & Cycle I & Cycle II \\
\hline Excellent & $\mathbf{9 0 - 1 0 0}$ & $\mathbf{2}$ & $\mathbf{5}$ & $\mathbf{1 2 . 5}$ & $\mathbf{3 1 . 2 5}$ \\
\hline Very Good & $\mathbf{8 0 - 8 9}$ & & $\mathbf{1 0}$ & & $\mathbf{6 2 . 5}$ \\
\hline Good & $\mathbf{7 0 - 7 9}$ & & & & \\
\hline Fair & $\mathbf{6 0 - 6 9}$ & $\mathbf{1 2}$ & & $\mathbf{7 5}$ & \\
\hline Poor & $\mathbf{0 - 5 9}$ & $\mathbf{2}$ & $\mathbf{1}$ & $\mathbf{1 2 . 5}$ & $\mathbf{6 . 2 5}$ \\
\hline Total & & $\mathbf{1 6}$ & $\mathbf{1 6}$ & $\mathbf{1 0 0}$ & $\mathbf{1 0 0}$ \\
\hline
\end{tabular}

The data above can also be shown in the graphic below:

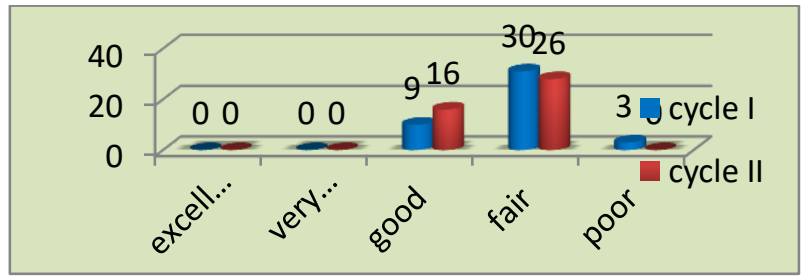

Graphic 6: The Students' Tabulation of Frequency in Distinguish phonemes.

Based on the table 6 and the graphic 6 above show that in cycle I there are 2 students $(12.5 \%)$ get excellent 12 students $(75 \%)$ get fair and there are 2 students $(12.5 \%)$ get poor. While in cycle II there are 5 students (62.5\%) get excellent, 10 students (62.5) and there is 1 student $(6.25 \%)$ get poor.

\section{Listening Achievement}

The students' improvement in listening achievement

Table 7. The Students' Improvement in Listening Achievement

\begin{tabular}{cccc}
\hline D-test & Cycle & Improvement & Mean score \\
\hline \multirow{2}{*}{50.69} & I & 28.78 & 65.28 \\
\cline { 2 - 4 } & II & 16.31 & 75.93 \\
\hline
\end{tabular}


The data above can also be shown in the graphic below:

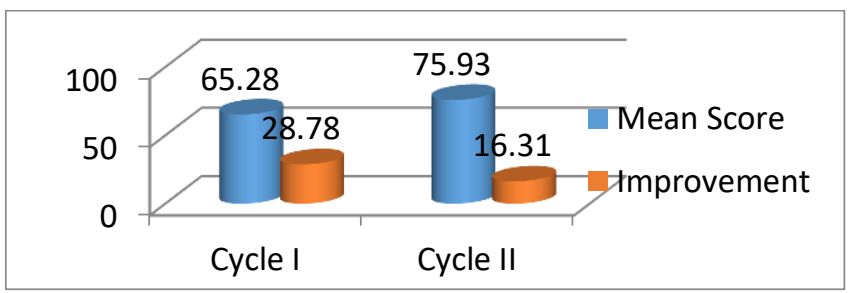

Graphic 7: The Improvement of the Students' Listening Achievement

\section{The students' Tabulation of Frequency in Listening Achievement}

Based on the data analysis the students score in writing result are got from the result of the test in cycle I and cycle II in the following table and graphic is presented:

Table 8. The Students' tabulation of listening achievement

\begin{tabular}{cccccc}
\hline Classification & \multirow{2}{*}{ Score } & \multicolumn{2}{c}{ Frequency } & \multicolumn{2}{c}{ Percentage } \\
\cline { 3 - 6 } & & Cycle I & Cycle II & Cycle I & Cycle II \\
\hline Excellent & $\mathbf{9 0 - 1 0 0}$ & & & & \\
\hline Very Good & $\mathbf{8 0 - 8 9}$ & & 3 & & 18.75 \\
\hline Good & $\mathbf{7 0 - 7 9}$ & $\mathbf{2}$ & $\mathbf{1 1}$ & $\mathbf{1 2 . 5}$ & $\mathbf{6 8 . 7 5}$ \\
\hline Fair & $\mathbf{6 0 - 6 9}$ & $\mathbf{1 0}$ & $\mathbf{2}$ & $\mathbf{6 2 . 5}$ & $\mathbf{1 2 . 5}$ \\
\hline Poor & $\mathbf{0 - 5 9}$ & $\mathbf{4}$ & & $\mathbf{2 5}$ & \\
\hline Total & & 16 & $\mathbf{1 6}$ & $\mathbf{1 0 0}$ & 100 \\
\hline
\end{tabular}

The data above can also be shown in the graphic below

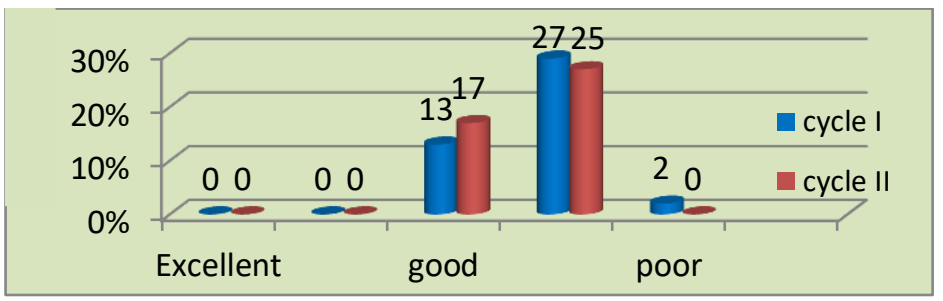

Graphic 8: The Students' tabulation of frequency in listening achievement

Based on the table 8 and the graphic 8 above show that in cycle I there is no student get excellent and very good. There are $2(25 \%)$ of the students get good, 10 $(62.5 \%)$ of students get fair while students who get poor are $4(25 \%)$. In cycle II there 
is no student get excellent and good. There are 3 (18.75) students, $11(68.75 \%)$ students who get good and $2(12.5 \%)$ students who get fair.

\section{The Students' Mean Score in Listening Achievement}

The students' improvement in listening achievement can be shown in the mean score from D-Test to cycle II below:

Table 9. The students' Mean Score in Listening Achievement

\begin{tabular}{ccc}
\hline \multicolumn{3}{c}{ Mean score } \\
\hline D-Test & Cycle I & Cycle II \\
\hline 50.69 & 65.28 & 75.93 \\
\hline
\end{tabular}

The students' improvement in their listening achievement can be shown through the graphic below:

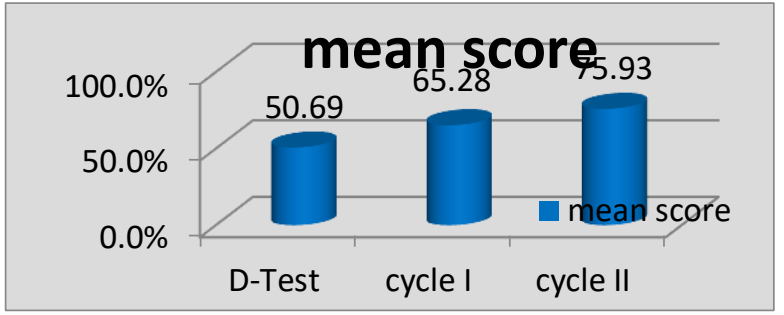

Graphic 9: The Students' Mean score in Listening Achievement

\section{Observation Result}

The following table and graphic show the observation result of the students' activeness in learning writing from cycle I to cycle II.

Table 10. The students' Observation Result During Teaching and Learning Process

\begin{tabular}{ccccc}
\hline \multirow{2}{*}{ Cycles } & \multicolumn{4}{c}{ Activeness } \\
\cline { 2 - 5 } & $\begin{array}{c}\mathbf{1}^{\text {st }} \text { Meeting } \\
(\boldsymbol{\%})\end{array}$ & $\begin{array}{c}\mathbf{2}^{\text {nd }} \text { Meeting } \\
(\boldsymbol{\%})\end{array}$ & $\mathbf{3}^{\text {rd }}$ Meeting $(\boldsymbol{\%})$ & $\begin{array}{c}\mathbf{4}^{\text {th }} \text { Meeting } \\
(\boldsymbol{\%})\end{array}$ \\
\hline Cycle 1 & 62.5 & 59.6 & 65.6 & 82.8 \\
\hline Cycle 2 & 70.3 & 67.2 & 71.9 & 92.2 \\
\hline
\end{tabular}


The students' observation can be shown through the graphic below:

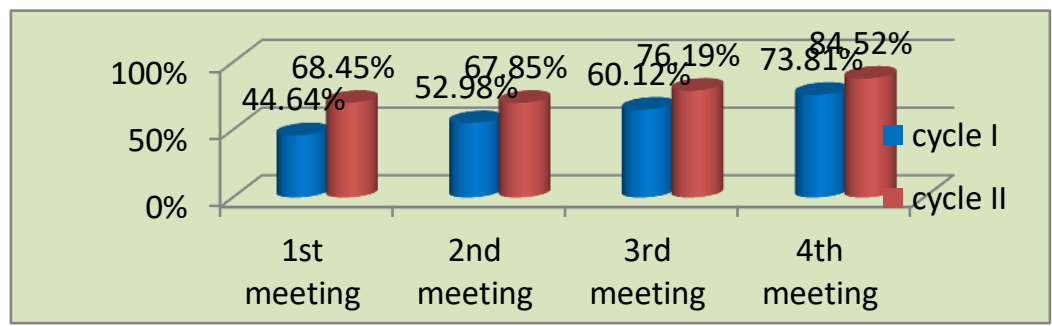

Graphic 10: Improvement of the Students' activeness during Teaching and Learning Process

Table 10 and graphic 10 above show that in cycle I the students' activeness in the $1^{\text {st }}$ meeting is $62.5 \%$, the $2^{\text {nd }}$ meeting is $59.4 \%$, the $3^{\text {rd }}$ meeting is $65.6 \%$ and the $4{ }^{\text {th }}$ meeting is $82.8 \%$. In cycle II students' activeness in the $1^{\text {st }}$ meeting is $70.3 \%$, the $2^{\text {nd }}$ meeting is $67.2 \%$, the $3^{\text {rd }}$ meeting is $71.9 \%$ and the $4^{\text {th }}$ meeting is $92.2 \%$. Base on the interpretation of the table and the graphic above indicate that the activeness of students in learning process always grow up from the first meeting in cycle I . For the first meeting of cycle II students probably get bored of material so their activeness decrease but researcher tries to engage them. It makes their activeness increase again until the last meeting in cycle II.

\section{DISCUSSION}

\section{The effectiveness of Aural-Oral Language Approach to improve the students' listening comprehension.}

The method which implemented in this study shows the effect to the students' listening achievement or the effectiveness of the method used. The data showed any improvement for listening component of distinguish phonemes namely the improvement of students' mean score achievement from cycle 1 to cycle 2. From the result of those tests namely from D-test to cycle II indicates that there was a significant improvement of students' mean score achievement in distinguish phonemes from D-test to cycle II namely 31.24. For the students' achievement in understanding statements, this method had applied twice in cycle 1 and two. In cycle one was found difficulties in analyzing statements because the students was less of skill in tenses as the element of listening comprehension. Based on the unsuccessful teaching in the cycle 1 , the researcher decided to do cycle 2 . In the cycle 2 , the researcher revised the lesson plan.

Where, when the researcher explained about how to analyze the meaning of the sentences then made opinion based on the sentence the researcher should explain more clearly, if needed gave the students occasion to ask about the material. Besides that, the researcher had to give better guidance for the student in analyzing statements. Furthermore, after implementation of Aural-oral approach in the class, the 
result found any improvement that the mean score of data source from D-Test in understanding statements was 45.58. In the cycle 1, the students got 47.91, and in the cycle 2 , the students got 50 .

The implementation of the test until twice was supported in the aural-oral structures. In language classes at these centers the teacher will say a word, phrase, or sentence and ask the students in the class to say the same word, phrase, or sentence aloud, both individually and as a group. This process is repeated until all of the students in the class can say a given word, phrase, or sentence with more or less the same pronunciation and speed as the native speaker instructor. Then the teacher will go on to the next word, phrase, or sentence in a lesson and repeat the whole process again. (http://japaneseforeveryone.com)

\section{The Improvement of the Students'Achievement in Listening Achievement.}

Listening achievement is what students have reached in learning process then they understanding it and produce it become sound in answer or gesture in action. In other words mean that a listener is far from passive as he receives, analyze, and interpret the oral signal that come his way, recreating the massage of the speaker or attending to and interpreting oral language interpreting oral language.

Finally, the findings of classroom action research dealing with the answer of the problem statement which aims to improve students' achievement was by listening test. Listening achievement here include distinguish phonemes and understanding statement dialogue. The table 7 and the graphic 7 show the improvement of the students' listening achievement and the mean score of the students. In the students' listening achievement D-test, the mean score is 50.69. Then in cycle I shows that the students' improvement in listening achievement from the D-test to cycle I is 28.78 , and the mean score is 65.28 . In cycle II shows the students' improvement in listening achievement from cycle I to cycle II is 10.65 and the mean score is 75.93.

The research findings from the table and graphic indicate that there was a significant improvement of the students' score in listening achievement from D-Test to cycle II, where in cycle I the improvement of students' score is 28.78 , after implementing Aural-Oral Approach and giving evaluation in the end of cycle II the improvement of the students' score becomes 16.31 .

\section{The Improvement of the Students' Activeness During the Teaching and Learning Process}

Table 8 and graphic 8 on the findings above show that in cycle I the students activeness in the $1^{\text {st }}$ meeting is $62.5 \%$ its mean that there is still the other activity that the students were done during the teaching and learning process. After repair the weakness that faced during the teaching and learning process. The students join until the end of cycle II, the students' activeness in the last meeting becomes $82.8 \%$. Its mean that the students pay full attention during teaching and learning process and there is no another activity that the students were done. The students are joining the 
teaching and learning process seriously. It means that, the application of Aural-oral approach could improve the students' activeness during teaching and learning process and it is successful.

Related to the learning process on the use of Aural-oral method in improving students listening comprehension, it had been done through classroom action research. The activities that teacher did namely, planning, action, observation and reflection that those are did in two cycle. Planning here means the teacher should Understanding the curriculum, the teacher prepared the material that would be used in listening class. the teacher made lesson planning for the first meeting, the second meeting, the third meeting, and the fourth meeting, made observation paper to observe the students activity, then the last was arranged the test to know their listening comprehension before taught them by using Aural-oral language approaches.

The action here means that the teacher began with warming up to stimulate students' motivation and attention, the teacher introduced Aural-Oral method and gave a short explanation about it before giving the material related to the scope of the study, the teacher used mechanical drill and repetition to make it clear after the students listen to the tape recorder or trough orally presentation from the teacher, the teacher also attempted to mimic some words or expression and asked the students to repeat those expressions, the students were divided into group if the teaching material includes difficult to do in personal, the teacher explained to the students what is going to do it included mark the list which is wrong or right for phonemes discrimination test and understanding statement.

For the listening comprehension test which covers understanding dialogues the students were asked to summarize or retell the main idea of the dialogue based on their own words to measure their comprehend in listening. For the listening comprehension test which covers understanding statements the students heard a statement may on tape recorder or orally and then choose the best opinion from three written paraphrases. Deal with observation here means that Students' present, Students' learning process, the students' respond of the material, the students' active in doing the task. The last activities the value of the observation steps was gathered for data analysis and evaluation by the observer, in the cycle I the researcher found that the students still weak in distinguishing phonemes if the phonemes were in the middle of sentence. The students also had difficult to understand statements; they could not analyze what the statement was talking about. In field of understanding dialogue, the students faced difficulty arranged the answer in grammatically although their idea was true. The data was used to do the next cycle. 
Related to the theory which is supported this method of the practical of auraloral in the classroom by (Larsen, 2018). He emphasized drilling to activities. Drilling is a key feature of Audio-Lingual Method as the result of Aural-Oral language approach to language teaching which placed emphasis on repeating structural patterns through oral practice. There are some good points that teachers may find when they use Aural-Oral Method in their teaching, namely: (1) the classroom activity, which is the teacher's centered so that it makes the teacher easier to manage the students (2) the usage of the target language in the classroom, which is meant to make the students have the same abilities that the native speakers have (3) the classroom activity, which focuses on pattern drills so that the teacher only gives brief explanation, and focus on oral skills leading to good pronunciation and speech Based on the interpretation of the table and the graphic on the findings above, indicate that there is a significant improvement of the students' activeness during teaching and learning process from the first meeting in the cycle I until the last meeting in cycle II.

\section{CONCLUSION}

Based on the research findings and discussions in the previous chapter, I assume a conclusion that Aural-oral approach was very effective to improve the students' listening comprehension at the eleventh grade students' of SMA 1 Makassar. The improvement of learning and students' activeness toward teaching learning process by using Aural-oral approach can be seen from their observation result of the students' activeness in the classroom from the first meeting at the first cycle until at the last meeting in cycle II always grow up. Furthermore, to reach students' achievement of learning listening comprehension was easier through the implementation of Aural-oral approach follow the principal working of classroom action research than the other method.

\section{REFERENCES}

Abduh, N. B. (2016). The Use of Audio-Lingual Method in Teaching Listening Comprehension At the Second Year Students of SMK Yapip Makassar Sungguminasa. Exposure: Jurnal Pendidikan Bahasa dan Sastra Inggris, 5(1), 43-53. https://doi.org/10.26618/ejpbi.v5i1.808

Agulló \& Bueno, A, (2017). Analysis of Oral Skills Development in the Most Used English Language Textbooks in the Second Year of Baccalaureate in Spain. Porta Linguarum, 27(2), 107-121.

Ahmadi, S. (2016). The Importance of Listening Comprehension in Language Learning Through effective Aural-Oral-Audio. International Journal of Research in English Education, 1(1), 7-10. http://ijreeonline.com/browse.php?a_code=A-10-1-2\& 
Butler, B. (2017). Historical older of Aural Listening in Insights Into Student Listening From Paused Transcription. The CATESOL Journal, 29(2), 81-108.

Buck, G. (2001).Assessing Listening Assessing Listening. https://books.google.co.uk/books?hl=en\&lr=\&id=m6fvKGi8b_IC\&oi=fnd\&p $\mathrm{g}=\mathrm{PR} 1 \& \mathrm{dq}=$ assessing + listening \&ots $=\mathrm{eHx} 8 \mathrm{~N} 1 \mathrm{bxph} \& \operatorname{sig}=\_$HchXUODPpJDoi QN1Hlq9vG0fCI

Gilakjani, A., P., \& Sabouri, N. B. (2016). Learners' Listening Comprehension Difficulties in English Language Learning: A Literature Review. English Language Teaching, 9(6), 123-133. https://doi.org/10.5539/elt.v9n6p123

Huang, H. (2009). How to Teach Aural English More Effectively. English Language Teaching, 2(3). 50-60 https://doi.org/10.5539/elt.v2n3p213

Itticharoenporn, (n.d.). Oral and Aural English As A Foreign Language Needs At An International School University of Hawai ' $i$ at Mānoa. 32(2014), 26-75.

Ivone, F. M., \& Renandya, W. A. (2019). Extensive listening and viewing oral-aural in ELT. Teflin Journal, 30(2), 237-256. https://doi.org/10.15639/teflinjournal.v30i2/237-256

Kayalar, F., \& Kayalar, F. (2017). The effects of Auditory Learning Strategy on Learning Skills of Language Learners (Students' Views). IOSR Journal Of Humanities And Social Science (IOSR-JHSS, 22(10), 4-17. https://doi.org/10.9790/0837-2210070410

Larsen, J., B., Vega, A., \& Ribera, J., E. (2008). The effect of room acoustics and sound-field amplification on word recognition performance in young adult listeners in suboptimal listening conditions. American Journal of Audiology, 17(1), 50-59. https://doi.org/10.1044/1059-0889(2008/006)

Namaziandost, E., \& Nasri, M. (2019). the Impact of Using Audio-Visual Aids on Teaching Listening Among Iranian Pre-Intermediate Efl Learners. 22(1), 4657.

Sharp, D. J., Chew-graham, C. A., Tylee, A., Lewis, G., Howard, L., Anderson, I., Abel, K., Turner, K. M., Hollinghurst, S. P., Tallon, D., \& Mccarthy, A. (2010). Trial To Compare Antidepressants With a. Health Technology Assessment, 14(43).

Zulfiqar A. Bin Tahir, S. (2015). Improving Students' Speaking Skill through Yahoo Messenger at University of Iqra Buru. International Journal of Language and Linguistics, 3(3), 174. https://doi.org/10.11648/j.ijl1.20150303.20 